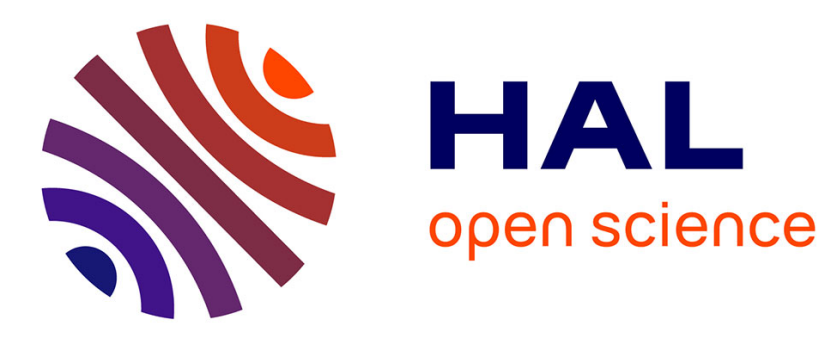

\title{
Rediscovery of af orgotten Mediterranean Chaetomorpha species in the Venice Lagoon (North Adriatic Sea): Chaetomorpha stricta Schiffner (Cladophorales, Chlorophyta)
}

Adriano Sfriso, Marion Adelheid Wolf, Isabella Moro, Andrea A Sfriso, Alessandro Buosi, Marc Verlaque

\section{To cite this version:}

Adriano Sfriso, Marion Adelheid Wolf, Isabella Moro, Andrea A Sfriso, Alessandro Buosi, et al.. Rediscovery of af orgotten Mediterranean Chaetomorpha species in the Venice Lagoon (North Adriatic Sea): Chaetomorpha stricta Schiffner (Cladophorales, Chlorophyta). Cryptogamie Algologie, 2018, 39 (3), pp.293-313. 10.7872/crya/v39.iss3.2018.293 . hal-01976056

\section{HAL Id: hal-01976056 https://hal.science/hal-01976056}

Submitted on 9 Jan 2019

HAL is a multi-disciplinary open access archive for the deposit and dissemination of scientific research documents, whether they are published or not. The documents may come from teaching and research institutions in France or abroad, or from public or private research centers.
L'archive ouverte pluridisciplinaire HAL, est destinée au dépôt et à la diffusion de documents scientifiques de niveau recherche, publiés ou non, émanant des établissements d'enseignement et de recherche français ou étrangers, des laboratoires publics ou privés. 


\title{
Rediscovery of a forgotten Mediterranean Chaetomorpha species in the Venice Lagoon (North Adriatic Sea): Chaetomorpha stricta Schiffner (Cladophorales, Chlorophyta)
}

\author{
Adriano SFRISO ${ }^{\text {***}}$, Marion Adelheid WOLF ${ }^{a^{* *}}$, Isabella MORO ${ }^{b}$, \\ Andrea A. SFRISO ${ }^{c}$, Alessandro BUOSI ${ }^{a} \&$ Marc VERLAQUE ${ }^{d^{*}}$ \\ ${ }^{a}$ Department of Environmental Sciences, Informatics and Statistics, \\ Ca' Foscari University of Venice, Via Torino 155, 30172 Venice, Italy \\ ${ }^{b}$ Department of Biology, University of Padova, Via U. Bassi, \\ 58/B 35131 Padova, Italy \\ ${ }^{c}$ Department of Molecular Sciences and Nanotechnologies, \\ Ca' Foscari University of Venice, Via Torino 155, 30172 Venice, Italy \\ ${ }^{d}$ Aix-Marseille University, CNRS, University of Toulon, IRD, \\ Mediterranean Institute of Oceanography (MIO), \\ UM 110 \& GIS POSIDONIE, 13288 Marseille, France
}

\begin{abstract}
On the basis of bibliographical, morphological and molecular studies (SSU rDNA), the reinstatement of species rank for Chaetomorpha stricta Schiffner, a poorly known Mediterranean endemic species described in the early 20th century, is proposed. Previously reduced to a posterior heterotypic synonym of $C$. linum (O.F. Müller) Kützing, C. stricta clearly differs from the latter by its small, light green, free-living filaments entangled in dense masses, the cells 0.5 to 1.6 (rarely 2) times as long as broad, with cell walls lamellate and broad up to 75-90 $\mu \mathrm{m}$ thick, and by molecular data. Chaetomorpha stricta was rediscovered, in May 2011, in oligotrophic clear waters of a closed fishing pond in the Valle Cavallino (northern basin of the Venice Lagoon). A critical review of Chaetomorpha taxa reported in the Mediterranean Sea and a taxonomic key to the Mediterranean taxa currently accepted are presented.
\end{abstract}

Chaetomorpha stricta / Taxonomy / Identification key / Venice Lagoon / Italy / Mediterranean Sea

Résumé - Sur la base d'une analyse bibliographique, morphologique et génétique (SSU rDNA), le rétablissement dans son rang d'espèce de Chaetomorpha stricta Schiffner, une espèce endémique méditerranéenne peu connue décrite au début du $\mathrm{XX}^{\mathrm{e}}$ siècle est proposé. Précédemment réduite au rang de synonyme hétérotypique de $C$. linum (O.F. Müller) Kützing, C. stricta diffère nettement de cette dernière par ses filaments non-fixés et enchevêtrés en masses denses, constitués de cellules 0,5 à 1,6 (rarement 2) fois plus longues que larges à 
parois cellulaires lamelleuses et très épaisses (jusqu'à 75-90 $\mu \mathrm{m}$ ), et par ses caractéristiques génétiques. Chaetomorpha stricta a été redécouverte, en mai 2011, dans les eaux claires et oligotrophes d'un étang de pêche de la Valle Cavallino (Bassin nord de la Lagune de Venise). Un inventaire critique des taxons de Chaetomorpha signalés en Méditerranée et une clé de determination des espèces méditerranéennes actuellement acceptées sont présentées.

\section{Chaetomorpha stricta / Taxonomie / Clé d'identification / Lagune de Venise / Italie / Méditerranée}

\section{INTRODUCTION}

Chaetomorpha Kützing (Cladophorales, Chlorophyta) is a cosmopolitan green algal genus characterized by attached or unattached, unbranched and polynucleate filaments without lateral rhizoids. Members of this taxon occur intertidally in marine and brackish waters (Leliaert \& Boedeker, 2007). Most Chaetomorpha species have relatively robust macroscopic thalli, and several species frequently form extensive mats of intertwining filaments that often cause green tides in different regions of the world (Flindt et al., 1997; Deng et al., 2013; Zhang et al., 2014). For example, in North China and Western Australia the massive growth of C. linum (O.F. Müller) Kützing mats has replaced other species in some lagoon areas, with a negative impact on seagrass ecosystems and benthic bivalves (Zhang et al., 2014).

The morphology of this genus is very simple, and only few characters are available to discriminate species, e.g.: attached or unattached growth, filament diameter, shape and size of the basal cells, length/diameter ratio of cells, presence of constrictions between cells (Leliaert \& Boedeker, 2007). For this reason, the taxonomy of Chaetomorpha is very problematic and so far 99 taxa have been reported, of which 70 are currently accepted taxonomically (Guiry \& Guiry, 2017). An example of the taxonomic complexity of the genus is illustrated by the species complex containing $C$. aerea (Dillwyn) Kützing and C. linum, two common algae widespread in warm and temperate waters and treated, according to the authors, as only one taxon or two different taxa. In addition to the morphological simplicity and the low number of diagnostic features, phenotypic plasticity, influenced by different environmental factors, can lead to overlapping morphological characters. These considerations highlight the need for molecular data to discriminate among species in the genus Chaetomorpha (Leliaert et al., 2009, 2011). Several molecular studies, based on gene sequence data of the ribosomal small subunit (SSU) or/and partial large subunit (LSU), were conducted to understand the relationships within Cladophorales (Bakker et al., 1994; Hanyuda et al., 2002; Leliaert et al., 2003, 2007; Boedeker et al., 2016).

In this study, we used morphological data coupled with phylogenetic analyses, based on the partial nuclear small subunit (SSU) rDNA, to discriminate a species of Chaetomorpha described from the Venice Lagoon (Italy) in the early 20th century and since forgotten: Chaetomorpha stricta Schiffner. 


\section{MATERIAL AND METHODS}

\section{Sampling and morphological study}

The species (hereafter: Valle Cavallino Chaetomorpha) was sampled, in May 2011, in Valle Cavallino during the assessment of the ecological status of the Venice Lagoon according to the 2000/60/EC requirements (Fig. 1). The Valle Cavallino Chaetomorpha was collected both from a boat with a rake and manually by SCUBA diving and the associated vegetation was identified. A subsample was dried in silica gel for genetic analyses and the rest was preserved in $4 \%$ formalin/ seawater for the morphological study. A voucher dried specimen was deposited at the Herbarium Patavinum (PAD) of the University of Padova, Italy, with the reference:

- A000622 - Chaetomorpha stricta Schiffner in Schiffner \& Vatova, collection Adriano Sfriso, Valle Cavallino (sexagesimal coordinates $45^{\circ} 29^{\prime} 30^{\prime \prime} \mathrm{N}$, $12^{\circ} 33^{\prime} 57^{\prime \prime}$ E), Venice Lagoon, Italy.

The material was compared with two syntypes of C. stricta Schiffner deposited at the Natural History Museum, London (BM), Department of Botany, with the following references:

- 000515933 (BM), labeled as Schiffner, Algae marinae $\mathrm{n}^{\circ} 232$, Chaetomorpha stricta Schiffn. n. sp., Val Perini, 12.12.1930, Commisione Internazionale del Mediterraneo, Ricerche nella LAGUNA VENETA, leg. A. Vatova, 25 May 1937.

- BM001044761, labeled as Schiffner, Algae marinae $\mathrm{n}^{\circ}$ 1233, Chaetomorpha stricta Schiffn. n. sp., Val Averto, 6.6.1932, Commisione Internazionale del Mediterraneo, Ricerche nella LAGUNA VENETA, leg. A. Vatova, 25 May 1937.

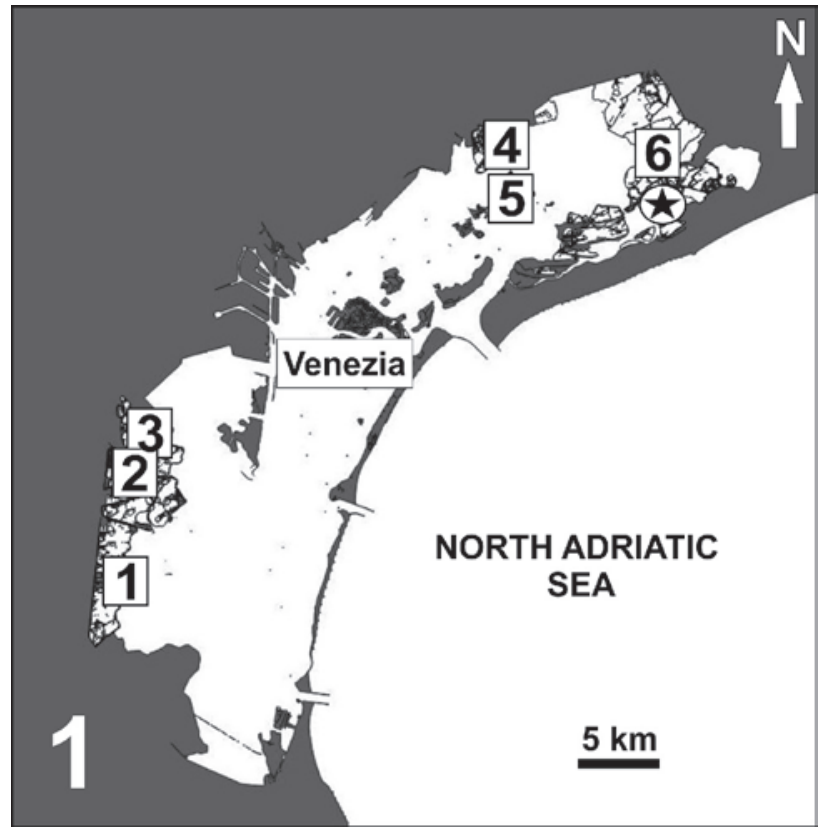

Fig. 1. The Venice Lagoon with the sampling site of Valle Cavallino (STAR) and the six syntype localities of Chaetomorpha stricta Schiffner (Schiffner \& Vatova, 1937): 1. Valle Morosina; 2. Val Averto; 3. Val Serraglia; 4. Val Perini; 5. Isola La Cura; 6. Val Grassabò. 
The study was completed by comparisons with species of Chaetomorpha deposited at the Herbarium HCOM of the Mediterranean Institute of Oceanography (MIO), Aix-Marseille University, in particular with the species possessing upper cells with thick and lamellate cell walls:

- C. ligustica (Kützing) Kützing - H8324, coll. Marc Verlaque, Sausset-les Pins, France, 23.09.2017, sea level.

- C. pachynema (Montagne) Kützing - H5634, coll. Marc Verlaque, Cala Petraghja, Corsica, 22.08.1992, 3 m depth.

Specimens were studied by means of Leica MZ16® and M80® stereo zoom microscopes and Leica $5000 \AA$ and Optiphot-2 Nikon ${ }^{\circledR}$ light microscopes equipped with a digital image acquisition system. A subsample of the Valle Cavallino specimen A000622 was treated according to Moro et al. (2010) and studied with a scanning electron microscope FEI Quanta 200® (Oregon, USA). Herbarium abbreviations follow Thiers (2015).

\section{Molecular analyses}

Genomic DNA extractions using the Genomic DNA purification kit (Thermo Scientific $^{\mathrm{TM}}$ ) were performed on the Valle Cavallino Chaetomorpha. The partial SSU gene was amplified using the primer pair SR-4 and 18S-6M (Hanyuda et al., 2002) under the following PCR conditions: initial denaturation step of $94^{\circ} \mathrm{C}$ for $3 \mathrm{~min}$, followed by 35 cycles of $94^{\circ} \mathrm{C}$ for $50 \mathrm{sec}, 50^{\circ} \mathrm{C}$ for $50 \mathrm{sec}, 72^{\circ} \mathrm{C}$ for $1 \mathrm{~min}$, followed by a final extension of $3 \mathrm{~min}$ at $72^{\circ} \mathrm{C}$. PCR products were cleaned by using the HT ExoSAP-IT (Applied Biosystems ${ }^{\mathrm{TM}}$ ). Sequencing of the amplified fragments was accomplished with the same primer pair at the BMR Genomics Sequencing Service (University of Padova, Italy). The SeqMan II program from the Lasergene software package (DNAStar(C), Madison, WI, USA) was used to assemble the final consensus sequence. Since the partial SSU sequences obtained for 9 samples of the Valle Cavallino Chaetomorpha were all identical, only one was deposited in the International Nucleotide Sequence Database (INSD) through the European Nucleotide Archive (ENA) platform with the following accession number: LT898516.

To infer the phylogenetic position of the Valle Cavallino Chaetomorpha, a dataset of 16 sequences belonging to different Chaetomorpha species was constructed (Table 1). The genus Siphonocladus F. Schmitz was chosen as outgroup [S. tropicus (P.Crouan \& H.Crouan) J.Agardh, accession number AM498761]. Sequences for comparison were downloaded from the USA National Center for Biotechnology Information (NCBI) web server (http:/www.ncbi.nlm.nih.gov). Sequence alignment was obtained by the ClustalW computer program (Thompson et al., 1994). Phylogenetic analyses were performed using the MEGA 5.1 (Molecular Evolutionary Genetics Analysis) program (Tamura et al., 2011) according to Neighbour Joining (NJ), Maximum Likelihood (ML), applying the T92 + G + I evolutionary model (Tamura, 1992), and Maximum Parsimony (MP) methods. Non-parametric bootstrap re-sampling (Felsenstein, 1985) was performed to test the robustness of the tree topology (1000 replicates).

\section{Bibliographical analysis}

A critical analysis of the literature was conducted to establish the exhaustive list of Chaetomorpha taxa described or reported from the Mediterranean. The diagnostic characters have been researched and critically analysed to identify the current taxonomic status of each taxon. 
Table 1. 18S rDNA sequences with accession numbers of Chaetomorpha species downloaded from GenBank for comparison with the Valle Cavallino Chaetomorpha (accession number: LT898516)

\begin{tabular}{|c|c|c|c|}
\hline Taxon & $\begin{array}{c}\text { Country } \\
\text { of the type locality }\end{array}$ & $\begin{array}{l}\text { Sampling area } \\
\text { or country }\end{array}$ & $\begin{array}{l}\text { Accession } \\
\text { No. }\end{array}$ \\
\hline C. aerea (Dillwyn) Kützing & England & North Sea, Germany & LT607325 \\
\hline C. antennina (Bory) Kützing & Réunion & KwaZulu Natal, South Africa & LT607328 \\
\hline C. clavata Kützing & West Indies & Panama & LT607334 \\
\hline C. coliformis (Montagne) Kützing & Probably Tasmania & Otago, New Zealand & LT607335 \\
\hline C. firma Levring & Juan Fernandez Isl. & Coquimbo, Chile & LT607336 \\
\hline C. ligustica (Kützing) Kützing & Italy & Zeeland, Netherlands & LT607340 \\
\hline C. linum (O.F.Müller) Kützing & Denmark & North Sea, Germany & LT607341 \\
\hline C. linum (O.F.Müller) Kützing & Denmark & Qingdao, China & JN540034 \\
\hline C. linum (O.F.Müller) Kützing & Denmark & Australia & KT593552 \\
\hline $\begin{array}{l}\text { C. melagonium (F.Weber \& D.Mohr) } \\
\text { Kützing }\end{array}$ & Sweden & Iceland & LT607342 \\
\hline C. moniligera Kjellman & Japan & Japan & LT607343 \\
\hline C. robusta (Areschoug) Papenfuss & South Africa & Cape Town, South Africa & LT607344 \\
\hline C. spiralis Okamura & Japan & Eastern Cape, South Africa & LT607345 \\
\hline $\begin{array}{l}\text { C. valida (J.D.Hooker \& Harvey) } \\
\text { Kützing }\end{array}$ & Tasmania & Rongcheng, China & JQ308276 \\
\hline C. vieillardii (Kützing) M.J.Wynne & New Caledonia & Kenya & LT607346 \\
\hline
\end{tabular}

\section{RESULTS}

Morphological description of the Valle Cavallino Chaetomorpha (Figs 2-7). Filaments free-living (basal cell not observed), light green, 10-20 cm long, entangled to form masses twisted or wrapped around other macrophytes; cells, 250-350 $\mu \mathrm{m}$ broad and 1-2 times as long as broad, with colourless lamellar cell walls, 48-75 $\mu \mathrm{m}$ thick; filaments frequently covered by calcareous algae, especially Pneophyllum fragile Kützing, cyanobacteria and diatoms belonging to the genus Cocconeis Ehrenberg.

Distribution: The Valle Cavallino Chaetomorpha was never found in the open lagoon or in other fishing ponds.

Habitat: The Valle Cavallino Chaetomorpha grew in oligotrophic clear waters of a closed fishing pond of the northern basin of the Venice Lagoon where it formed small entangled masses of filaments within the angiosperm shoots and other macroalgae. The species coexisted with the larger species $C$. linum, the only other species of Chaetomorpha recorded in Valle Cavallino. The environment of the fishing pond was characterized by high water quality and was prevalently populated by the angiosperms Ruppia cirrhosa (Petagna) Grande and Cymodocea nodosa (Ucria) Ascherson. The macroalgal vegetation of the Valle Cavallino is mainly composed of Lamprothamnium papulosum (K.Wallroth) J.Groves, a species never recorded in the open lagoon, Chaetomorpha linum (O.F.Müller) Kützing, Pneophyllum fragile, Polysiphonia spinosa (C Agardh) J. Agardh, and Valonia aegagropila C. Agardh. No Ulvaceae were recorded in the area.

DNA sequence available: LT898516 nuclear SSU rDNA. 


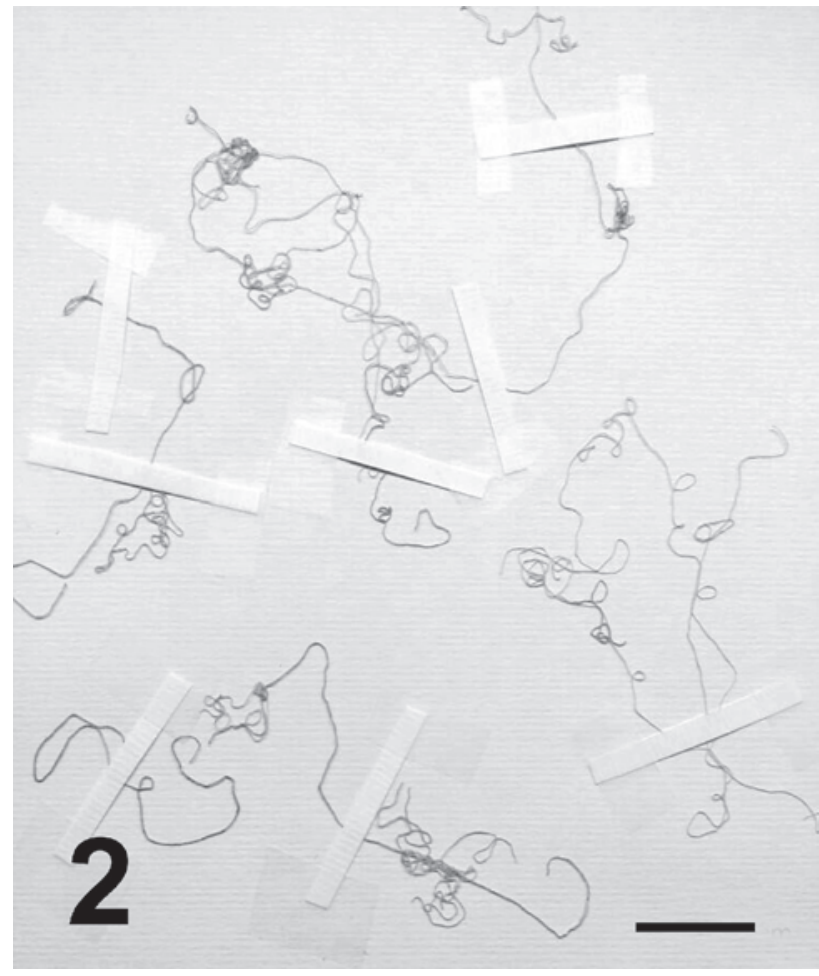

Fig. 2. Dried specimens (Ref. A000622) of Chaetomorpha stricta Schiffner collected in May 2011 in Valle Cavallino $\left(45.493611^{\circ} \mathrm{N}, \quad 12.566667^{\circ} \mathrm{E}\right)$, Venice Lagoon. Scale bar $=$ $2 \mathrm{~cm}$.

\section{Molecular analyses}

In the phylogenetic reconstruction, the SSU sequence of the Valle Cavallino Chaetomorpha was placed in a well-supported clade (NJ 100\%, ML 99\%, MP 99\% of bootstrap support) with samples belonging to $C$. linum and $C$. aerea from different regions of the world (Fig. 8). The nucleotide divergences of the Valle Cavallino Chaetomorpha and the sequences of the other specimens are: $0.30 \%$ with $C$. linum (Australia), $0.44 \%$ with $C$. linum (Germany and China) and $0.44 \%$ with $C$. aerea (Germany).

\section{Taxonomic analyses}

According to the literature analysed, a total of 43, 31 and 15 taxa of Chaetomorpha were reported from the Mediterranean Sea, the Adriatic Sea and the Venice Lagoon, respectively. Among them, 8 taxa were described from the Venice Lagoon (Table 2). Cormaci et al. (2014) reduced this list to only 4 accepted taxa:

- C. gracilis Kützing

- C. ligustica (Kützing) Kützing

- C. linum (O.F. Müller) Kützing

- C. pachynema (Montagne) Kützing

We agree with this treatment, except for two taxa: $C$. aerea and $C$. stricta. With regard to the taxonomic status of $C$. aerea, there are two different viewpoints. Some authors considered the taxon as a growth form of C. linum (Burrows, 1991; John et al., 2003; Leliaert \& Boedeker, 2007; Mystikou et al., 2016), in disagreement 


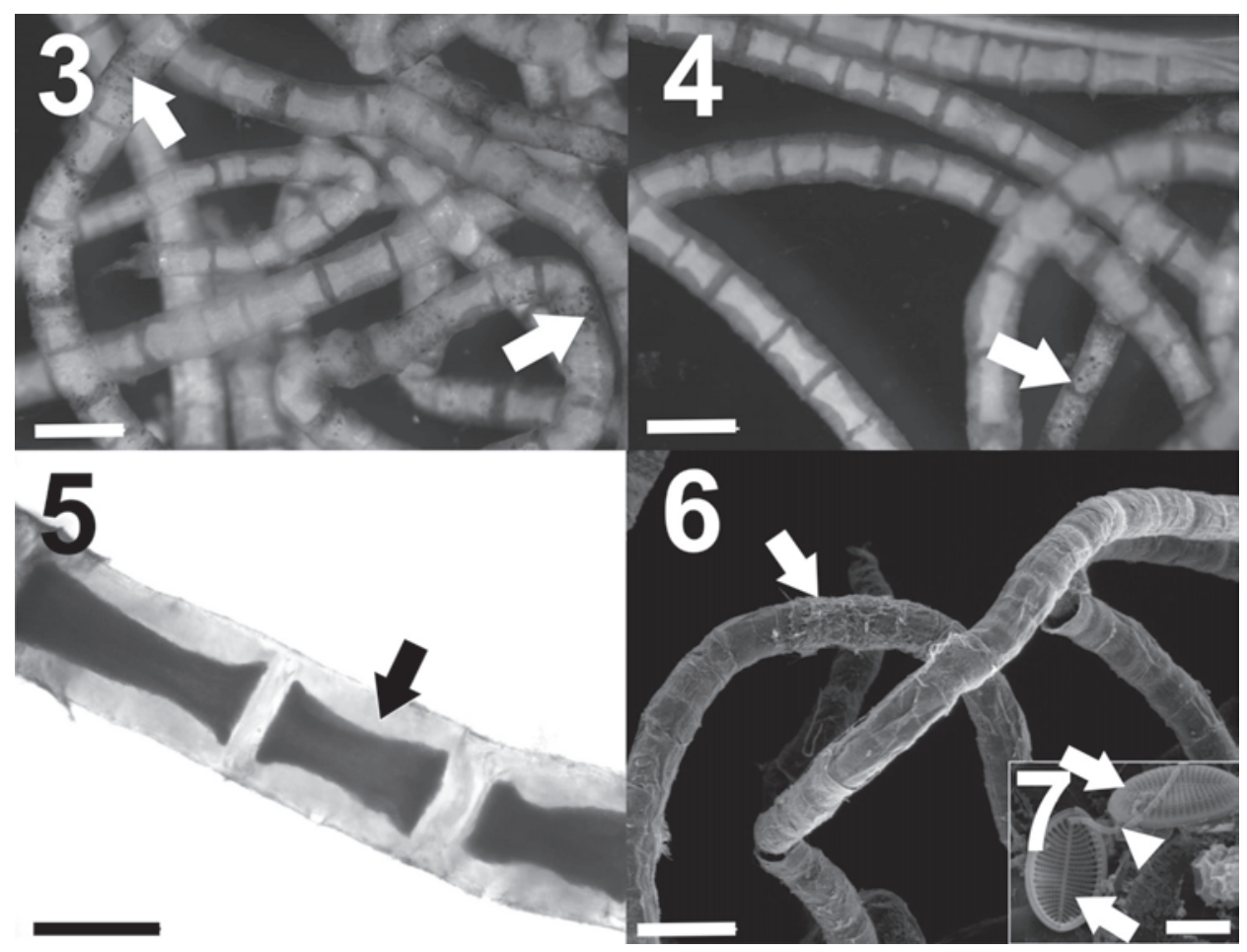

Figs 3-7. Chaetomorpha stricta Schiffner, (Specimen A000622) Valle Cavallino, May 2011. 3-4. Filaments with epiphytic calcareous taxa (arrows). 5. Details of cells showing the thick and lamellate cell walls (arrow), 6. Scanning electron microscope image of filaments showing epiphytes (arrows), 7. Detail of epiphytes; arrows: Cocconeis sp.; arrow head: Cyanobacteria. Scale bars: $3 \& 4=400 \mu \mathrm{m} ; 5=200 \mu \mathrm{m} ; 6=500 \mu \mathrm{m} ; 7=10 \mu \mathrm{m}$.

with others who reported $C$. aerea and $C$. linum as two separate entities (Stegenga \& Mol, 1983; Silva et al., 1996; Sfriso, 2010; Brodie et al., 2016; Huang et al., 2016). The relationship between these species is still uncertain (John et al., 2003). On this point, Sfriso (2010) highlighted that these taxa should also be considered as distinct entities on the basis of the different habitats they colonize: $C$. linum grows freefloating in environments covered by seagrasses whereas $C$. aerea is mostly present in eutrophic environments attached to hard substrata. On the basis of morphological data and ecological requirements, we chose to treat the two taxa separately in the critical review of Chaetomorpha reported in the Mediterranean Sea (Table 2).

Since its description from different parts of the Venice Lagoon (Schiffner \& Vatova, 1937) (Fig. 1), the status of C. stricta has changed over time. The species was successively reported, always without any description, in the Adriatic Sea: Venice Lagoon (Vatova, 1940), Trieste (Italy) (Pignatti \& Giaccone, 1967; Giaccone, 1969), Pianosa Island and Tremiti Islands (Italy) (Rizzi et al., 1967b; Giaccone, 1969; Rizzi Longo, 1972), Testa del Gargano (Italy) (Rizzi et al., 1967a; Giaccone, 1969), and Supetarska-Draga (Croatia) (Rizzi Longo, 1972a), and in the Tyrrhenian Sea: Costa dell'Argentario (Italy) (Rizzi Longo, 1972b, as "Chaetomorphastadio stricta Schiffn."). Subsequently, C. stricta was treated as taxon inquirendum (Gallardo et al., 1993), before being downgraded to a heterotypic synonym of 


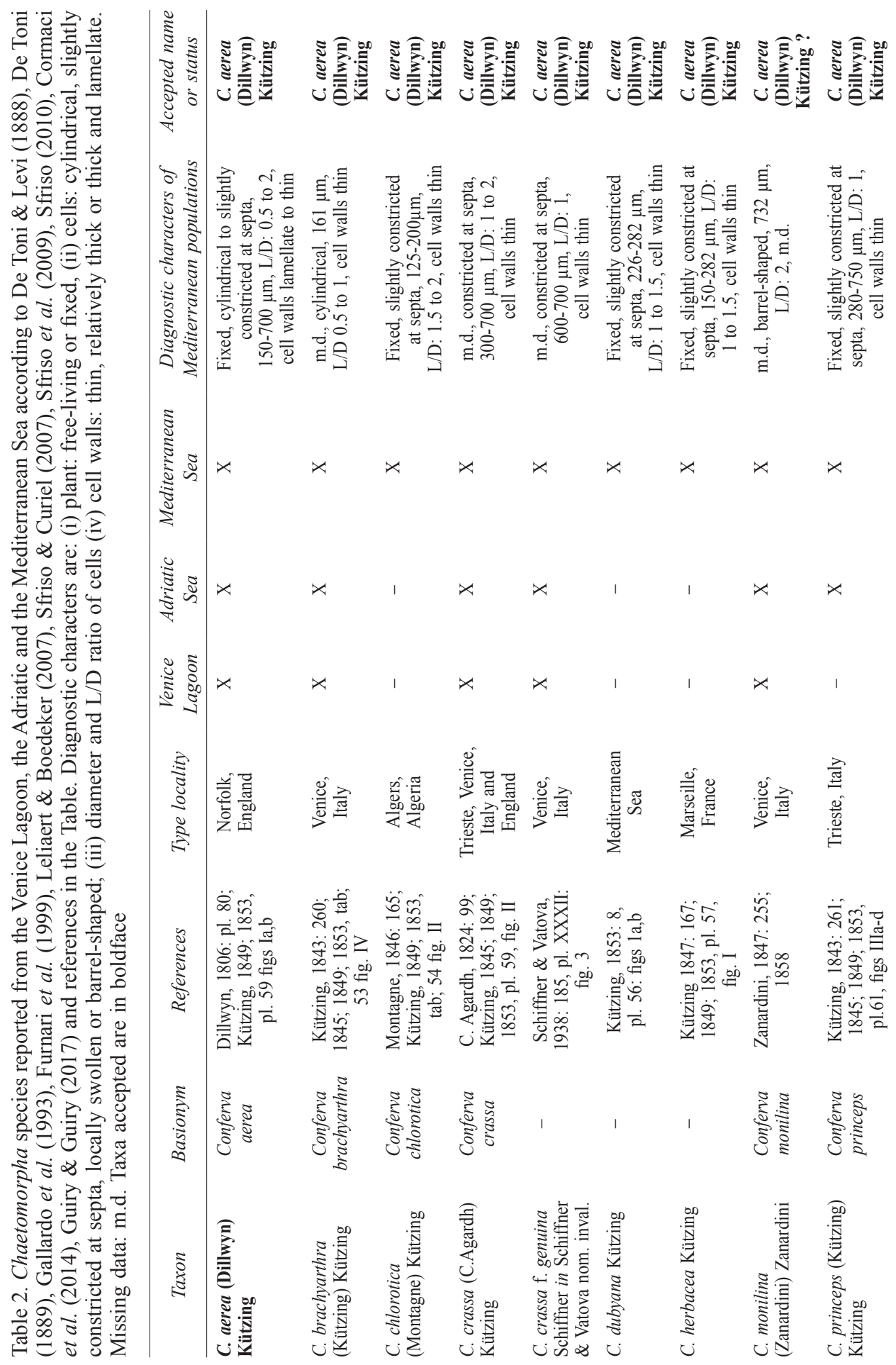




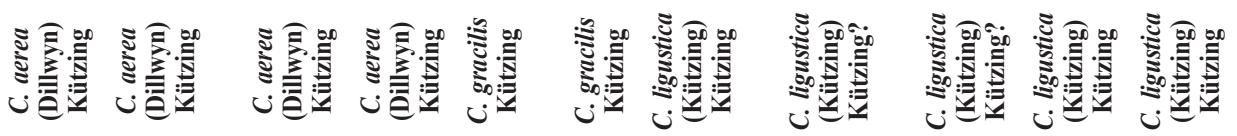

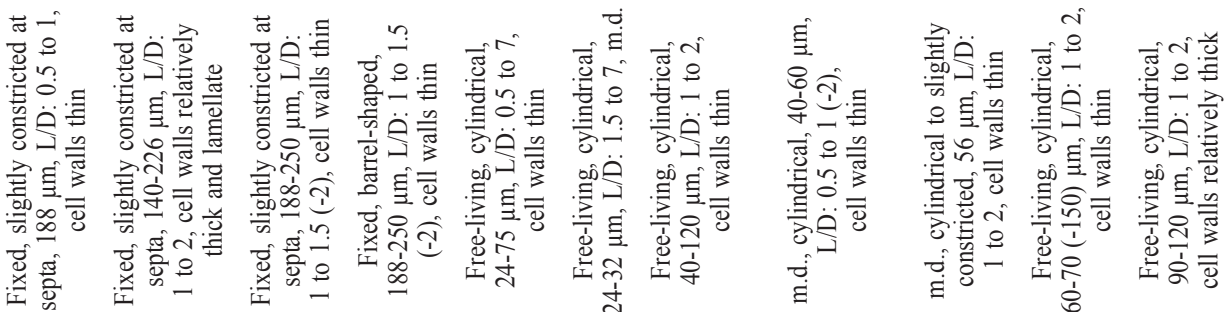

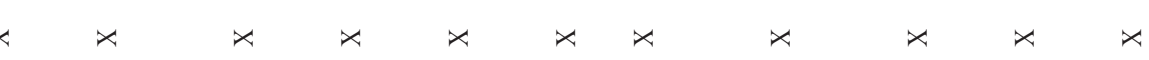

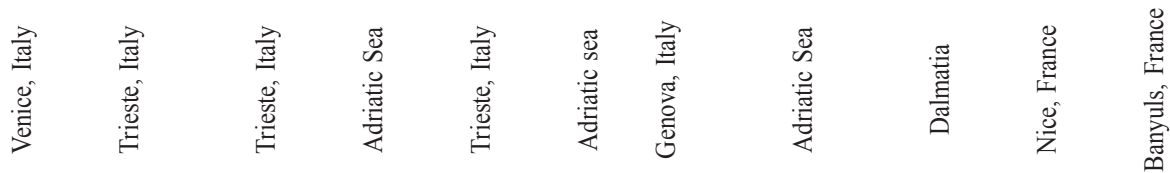

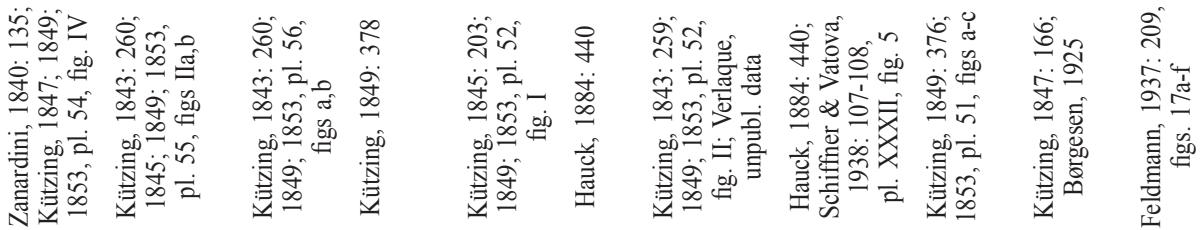

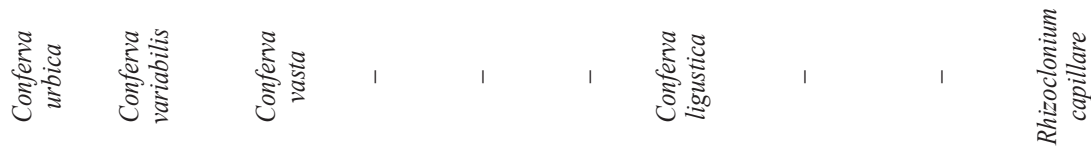

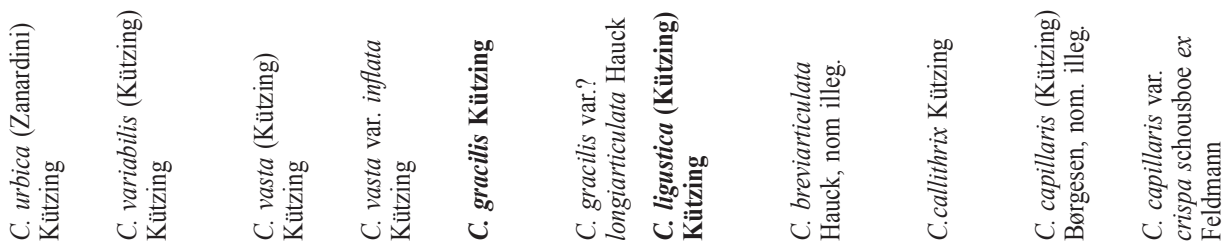




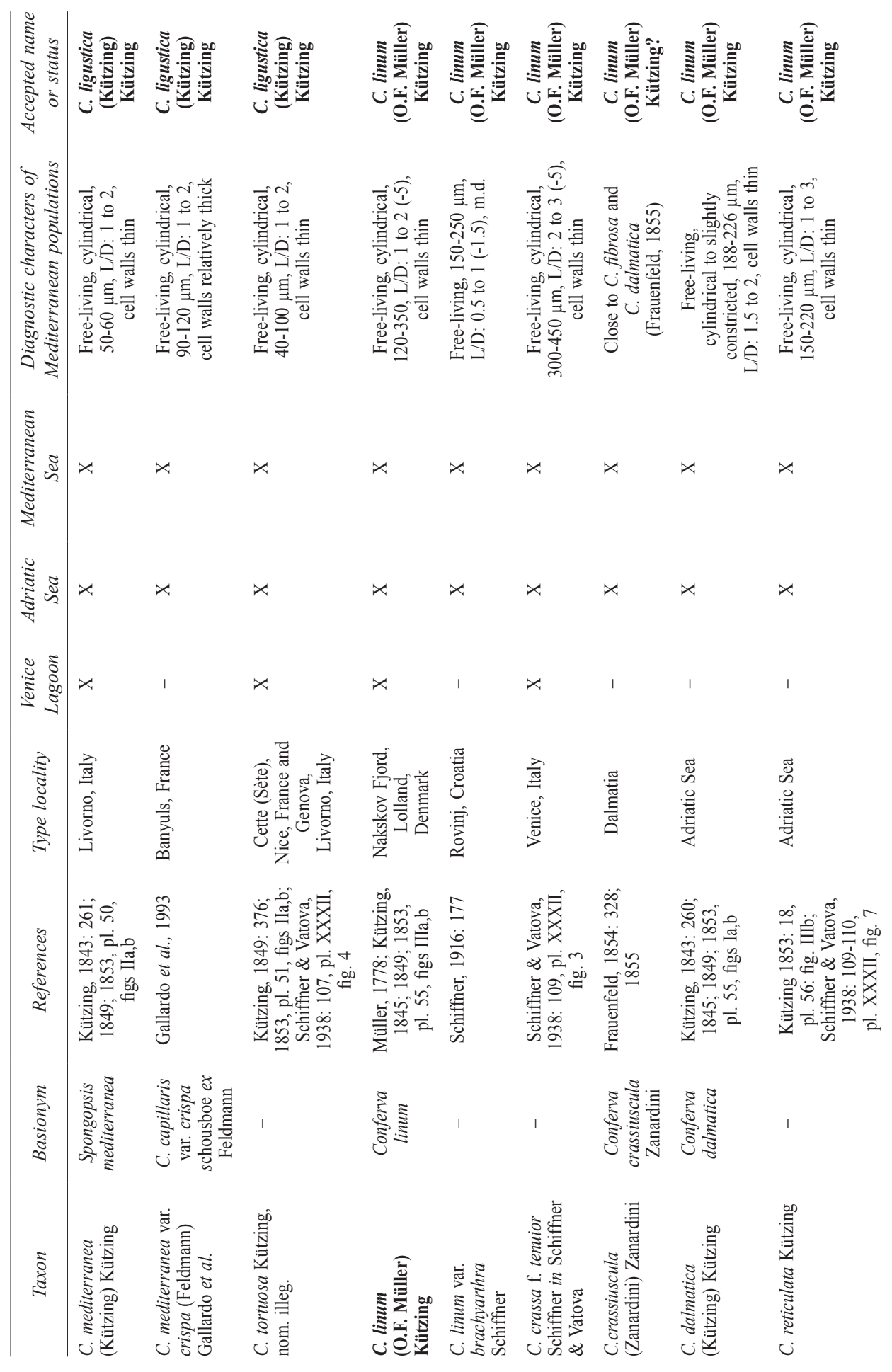




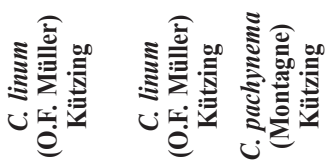

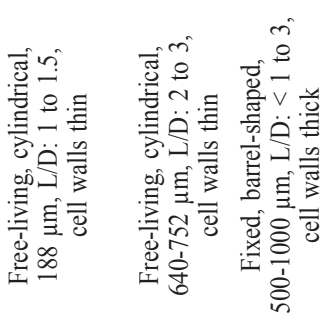

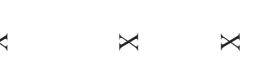

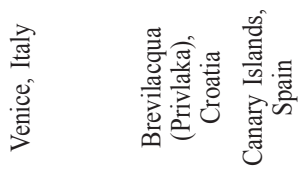

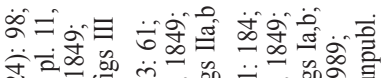

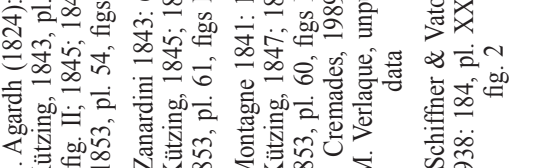

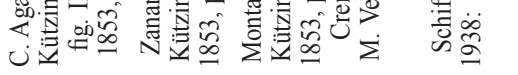

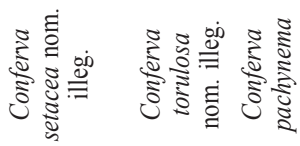

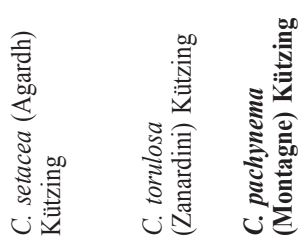

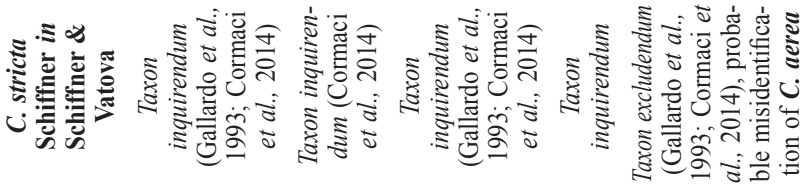

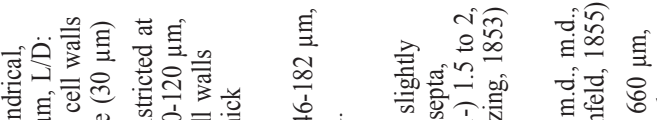

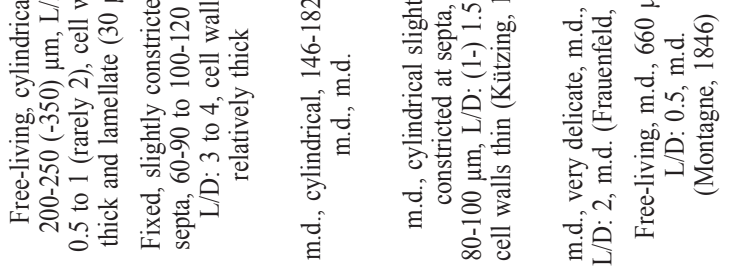

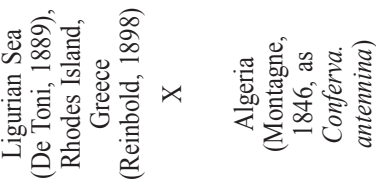

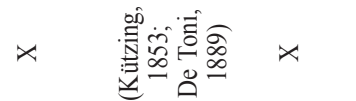

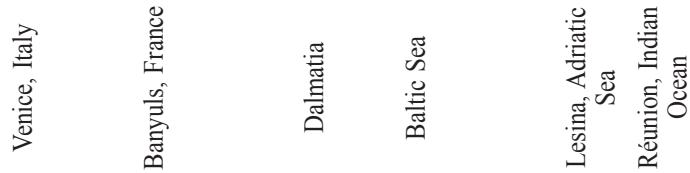

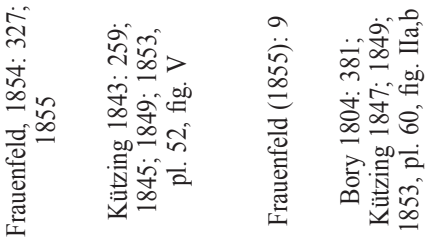

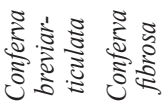

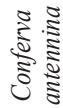

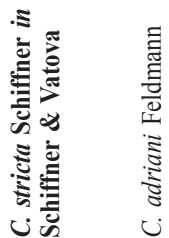

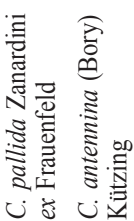




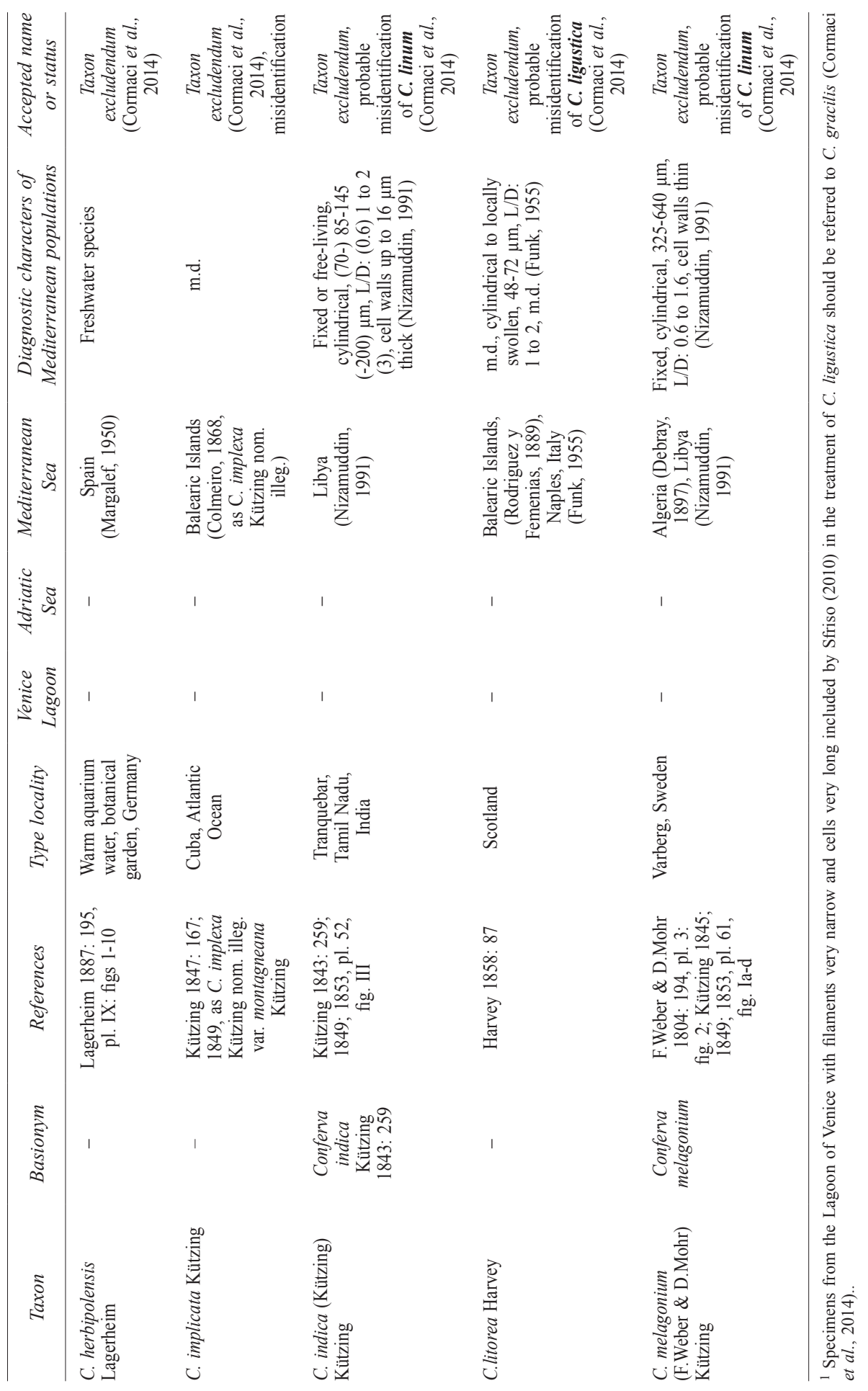


C. linum (Furnari et al., 1999, 2003; Cormaci et al., 2014). The comparison of diagnostic characters of the Valle Cavallino Chaetomorpha with the protologue of C. stricta and the two C. stricta syntypes deposited at the Natural History Museum, London (Figs 9-14), showed that they belong to the same taxon and that

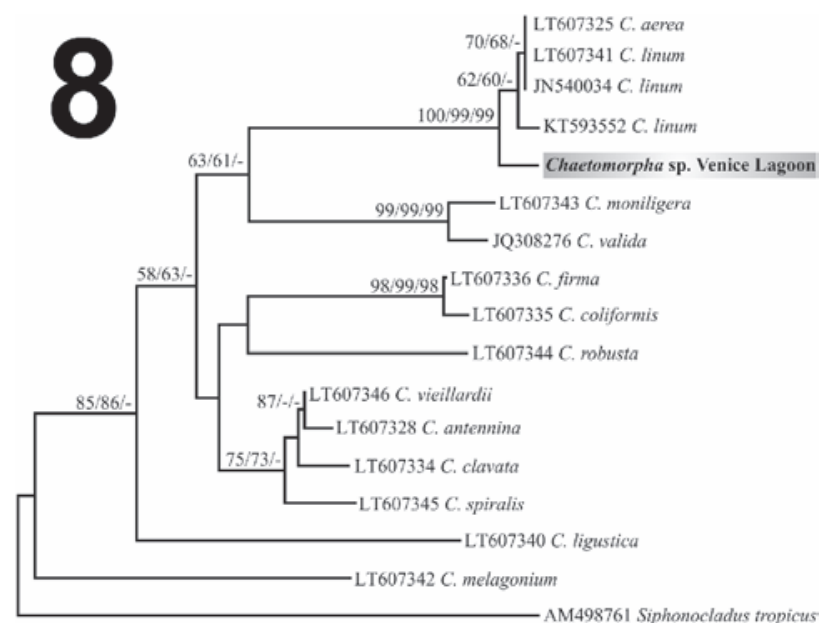

0.005

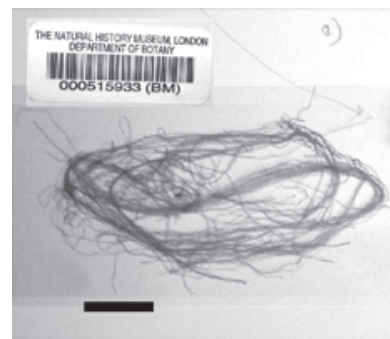

9

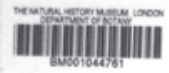

10

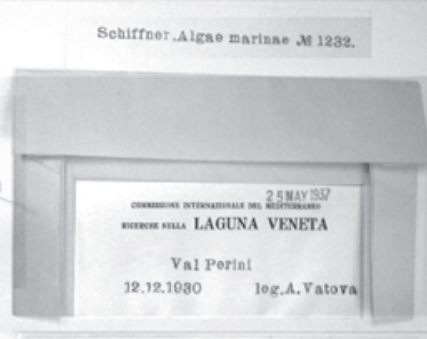

Sehiffner.Algae marinae $M 1233$.

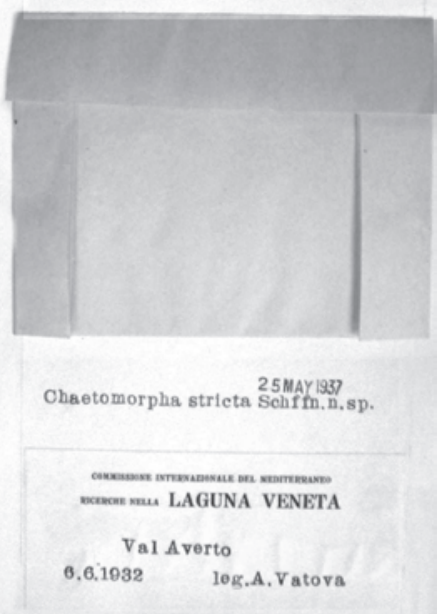

Fig. 8. ML tree inferred from partial SSU nrDNA sequences. New species sequence is in bold. NJ/ML/MP bootstrap values $(>50)$ are given at nodes.

Figs 9-10. Two syntypes of Chaetomorpha stricta Schiffner deposited at the Natural History Museum, London (BM). 9. Specimen BM 000515933, Val Perini, Laguna Veneta, 12 December 1930, leg. A. Vatova. 10. Specimen BM001044761, Val Averto, Laguna Veneta, 6 June 1932, leg. A. Vatova. Scale bars: 9 \& $10=2 \mathrm{~cm}$. 

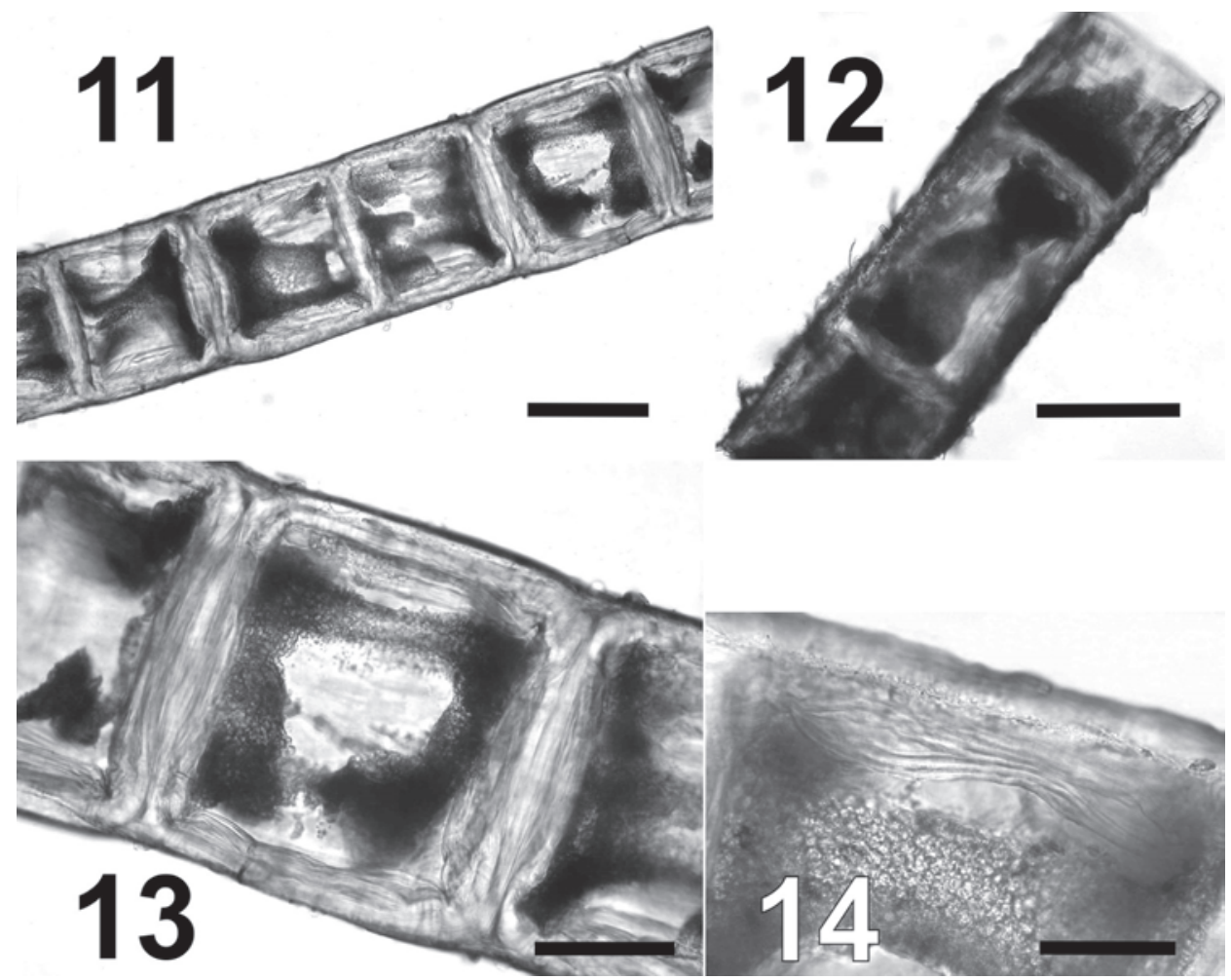

Figs 11-14. Syntype BM 000515933 of Chaetomorpha stricta Schiffner. 11. Part of a filament with isodiametric cells. 12. Part of filament with rectangular cells. 13-14. Details of cells showing the thick and lamellate cell walls. Scale bars: $11 \& 12=200 \mu \mathrm{m} ; 13=100 \mu \mathrm{m} ; 14=50 \mu \mathrm{m}$.

the reduction of $C$. stricta to a posterior heterotypic synonym of $C$. linum was unjustifiable. Chaetomorpha stricta is a species that differs very clearly from all the other Mediterranean species in having free-living filaments, 189-370 $\mu \mathrm{m}$ in diameter, with cylindrical cells and lamellate and thick cell walls up to $90 \mu \mathrm{m}$ thick (Table 3).

\section{DISCUSSION}

As highlighted by other authors, the morphological simplicity, the low number of diagnostic features and the phenotypic plasticity of species belonging to this genus makes necessary the use of molecular data to discriminate among different entities (Leliaert \& Boedeker, 2007; Leliaert et al., 2009, 2011). During the assessment of the ecological status of the Venice Lagoon according to the 2000/60/ EC requirements, we collected $C$. stricta Schiffner, a species described from the Venice Lagoon in the early 20th century, and subsequently erroneously downgraded to a heterotypic synonym of $C$. linum. In the ML tree obtained in this work, the nuclear SSU rDNA sequence of the $C$. stricta clustered with sequences belonging to two other species present in the lagoon, $C$. linum and $C$. aerea, but its phylogenetic 


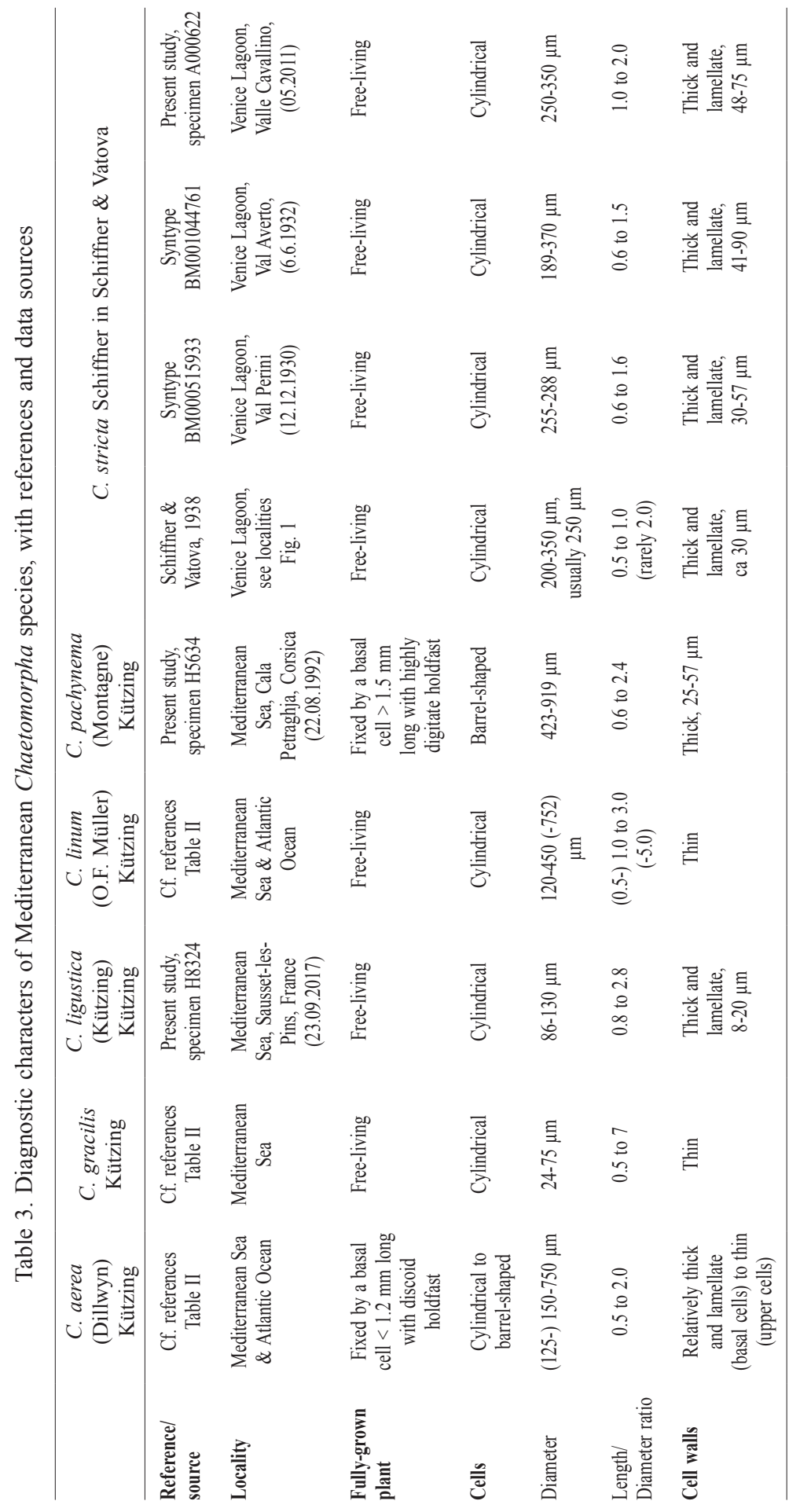


position is clearly distinct from them. A third species reported from the lagoon, C. ligustica, is phylogenetically distant from this clade. The nucleotide divergences calculated between $C$. stricta and the other species of the lagoon are greater than or comparable with the divergences found between other species of the same genus, e.g. C. viellardii - C. antennina $(0.15 \%)$, C. firma - C. coliformis $(0.15 \%)$ and C. viellardii $-C$. clavata $(0.44 \%)$. These results together with the morphological analyses support the species-level distinction of $C$. stricta.

Currently, six species of Chaetomorpha occur in the Mediterranean Sea (see below the Key to the Mediterranean Chaetomorpha species). All of them were reported from the Venice Lagoon, except for C. pachynema.

In the Venice Lagoon, the most abundant Chaetomorpha species are C. linum, C. gracilis and C. ligustica that can form blooms reaching many kilograms of biomass per square meter. The first is especially present in the southern lagoon in association with meadows of angiosperms, whereas $C$. gracilis and $C$. ligustica form a mixture that colonizes mostly eutrophic and turbid areas. All form long freeliving filaments which can exceed one meter in length. Chaetomorpha aerea is also common in eutrophic and turbid environments, but forms shorter filaments (10$30 \mathrm{~cm}$ long) that usually grow attached to hard substrata by a long basal cell. Although the protologue of C. stricta was based on material collected all around the Venice Lagoon, we hitherto observed the species in only one closed fishing pond of the Valle Cavallino (northern basin); consequently, it would be worth searching for this species in the rest of the Venice Lagoon and in other Mediterranean coastal lagoons, especially in the Adriatic Sea.

\section{Key to the Mediterranean Chaetomorpha species}

1. Adult plants fixed; cells cylindrical to barrel-shaped. .....................................2

Adult plants free-living; cells cylindrical .......................................................

2. Filaments, up to $3 \mathrm{~cm}$ long and 0.5 to $1 \mathrm{~mm}$ in diameter, fixed by a digitate holdfast; basal cell 1.5 to $3 \mathrm{~mm}$ long with cell walls $50-100 \mu \mathrm{m}$ thick

C. pachynema (Montagne) Kützing Filaments, up to $40 \mathrm{~cm}$ long and $150-700 \mu \mathrm{m}$ in diameter, fixed by a discoidal holdfast; basal cell up to $1.2 \mathrm{~mm}$ long with cell walls $<30 \mu \mathrm{m}$ thick.

C. aerea (Dillwyn) Kützing

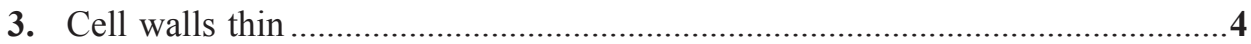

Cell walls thick and lamellate ...................................................................5

4. Cells $<100 \mu \mathrm{m}(24-75 \mu \mathrm{m})$ in diameter and 0.5 to 7 times as long as broad C. gracilis Kützing Cells $>100 \mu \mathrm{m}(120-450 \mu \mathrm{m}$, rarely more) in diameter and 0.5 to 3 (rarely 5) times as long as broad............................... linum (O.F. Müller) Kützing

5. Cells $<150 \mu \mathrm{m}(86-130 \mu \mathrm{m})$ in diameter and 0.8 to 2.8 times as long as broad; cell walls $8-20 \mu \mathrm{m}$ thick................................... ligustica (Kützing) Kützing Cells $>150 \mu \mathrm{m}(189-370 \mu \mathrm{m})$ in diameter and 0.5 to 1.6 (rarely 2 ) times as long as broad; cell walls $30-75(-90) \mu \mathrm{m}$ thick

C. stricta Schiffner

Acknowledgements. The authors wish to thank the Herbarium BM and Dr Jo Wilbraham, Senior Curator, Department of Life Sciences, Natural History Museum, London, for sending the two syntypes of $C$. stricta. The authors also wish to thank Michèle PERRETBOUDOURESQUE, Mediterranean Institute of Oceanology (Marseille), for documentation assistance, and Michael PAUL for revising the English language. 


\section{REFERENCES}

AGARDH C.A., 1824 - Systema algarum, pp. [i]-xxxvii, [1]-312. Lundae [Lund]: Literis Berlingianis [Berling], xxxvii, $312 \mathrm{p}$.

BAKKER F.T., OLSEN J.L., STAM W.T. \& HOEK C. van den, 1994 - The Cladophora complex (Chlorophyta): new views based on 18S rRNA gene sequences. Molecular phylogenetics and evolution 3: 365-382.

BOEDEKER C., LELIAERT F. \& ZUCCARELLO G.C., 2016 - Molecular phylogeny of the Cladophoraceae (Cladophorales, Ulvophyceae), with the resurrection of Acrocladus Nägeli and Willeella Børgesen, and the description of Lurbica gen. nov. and Pseudorhizoclonium gen. nov. Journal of phycology 52: 905-928.

BØRGESEN F., 1925 - Marine algae from the Canary Islands especially Teneriffe and Gran Canaria. I. Chlorophyceae. Kongelige Danske Videnskabernes Selskab, Biologiske Meddelelser 5(3): $1-123,49$ figs.

BORY DE SAINT-VINCENT J.B.G.M., 1804 - Voyage dans les quatre principales îles des mers d'Afrique ... pendant les années neuf et dix de la République (1801 et 1802), avec l'histoire de la traversée du Capitaine Baudin jusqu'au Port-Louis de l'Ile Maurice. I, Paris: Chez F. Buisson, pp. i-xv [xvi = errata], 1-408.

BURROWS E M., 1991 - Seaweeds of the British Isles. Vol. 2. Chlorophyta. London, Natural History Museum Publications, $238 \mathrm{p}$.

COLMEIRO M., 1868 - Enumeración de las Criptógamas de España y Portugal. Part. II. [Algas]. Revista progreso ciência 18: 180-218; 360-384; 431-441.

CORMACI M., FURNARI G. \& ALONGI G., 2014 - Flora marina bentonica del Mediterraneo: Chlorophyta. Bollettino dell'accademia gioenia di scienze naturali di Catania 47: 11-436.

CREMADES J., 1989 - Ethelia fissurata (Crouan frat.) Denizot y Chaetomorpha pachynema (Mont.) Mont. in Kütz. en las Islas Baleares. Anales jardin botanico de Madrid 46: 341-343.

DEBRAY F., 1897 - Catalogue des algues du Maroc, d'Algérie et de Tunisi., Alger: Librairie Adolphe Jourdan, $78 \mathrm{p}$.

DENG Y., TANG X., ZHAN Z., TENG L., DING L. \& HUANG B., 2013 - Culture observation and molecular phylogenetic analysis on the blooming green alga Chaetomorpha valida (Cladophorales, Chlorophyta) from China. Chinese Journal of oceanology and limnology 31: 552-599.

DE TONI G.B., 1889 - Sylloge algarum omnium hucusque cognitarum. Vol. I. Chlorophyceae, Patavii [Padua], sumptibus auctoris, pp. [3]-12, [i]-cxxxix, 1-1315.

DE TONI G.B. \& LEVI D., 1888 - Collezioni di storia naturale. I. Collezioni botaniche. L'Algarium Zanardini, Venezia: Civico Museo e Raccolta Correr, 144 p.

DILLWYN L.W., 1806 - British Confervae; or colored figures and descriptions of the British plants referred by botanists to the genus Conferva, London: W. Phillips, pls 57-68 \& 70-81 (with text).

FELDMANN J., 1935 - Algae marinae Mediterraneae novae. Bulletin de la société d'histoire naturelle de l'Afrique du Nord 26: 362-369.

FELDMANN J., 1937 — Les algues marines de la côte des Albères. I-III. Cyanophycées, Chlorophycées, Phéophycées. Revue algologique 9: 141(bis)-148(bis); 149-335, 67 figs, pls 8-17.

FELSENSTEIN J., 1985 - Confidence limits on phylogenies: an approach using bootstrap. Evolution 39: 783-791.

FLINDT M., SALOMONSEN J., CARRER M., BOCCI M. \& KAMP-NIELSEN L., 1997 — Loss, growth and transport dynamics of Chaetomorpha aerea and Ulva rigida in the Lagoon of Venice during an early summer field campaign. Ecological modelling 102: 133-141.

FRAUENFELD G., 1854 - Aufzählung der Algen der dalmatischen Küste. Verhandlungen des Zoologisch-Botanischen Vereins in Wein 4(Abh.): 317-350.

FRAUENFELD G., 1855 - Die Algen der dalmatischen Küste: mit Hinzufügung der von Kützing im adriatischen überhaupt ausgefürten Arten. Wien [Vienna], Druck und Verlag der Kaiserl. Königl. Hof. und Staatsdrukerel, pp. [i]-xviii, 1-78, 26 pls.

FUNK G., 1955 - Beiträge zur Kenntnis der Meeresalgen von Neapel: Zugleich mikrophotographischer Atlas. Pubblicazioni della stazione zoologica di Napoli 25 (Suppl.): i-x , 1-178, 36 figs.

FURNARI G., CORMACI M. \& SERIO D., 1999 - Catalogue of the benthic marine macroalgae of the Italian coast of the Adriatic Sea. Bocconea 12: 1-214.

FURNARI G., GIACCONE G., CORMACI M., ALONGI G. \& SERIO D., 2003 - Biodiversità marina delle coste italiane: catalogo del macrofitobenthos. Biologia marina Mediterranea, 10: $1-482$. 
GALLARDO T., GÓMEZ GARRETAA., RIBERA M.A., CORMACI M., FURNARI G., GIACCONE G. \& BOUDOURESQUE C.-F., 1993 - Check-list of Mediterranean Seaweeds, II. Chlorophyceae Wille s.1. Botanica marina 36: 399-421.

GIACCONE G., 1969 - Raccolte di fitobenthos sulla banchina continentale Italiana. Giornale Botanico Italiano 103: 485-514.

GUIRY M.D. \& GUIRY G.M., 2017 - AlgaeBase. World-wide electronic publication, National University of Ireland, Galway. http://www.algaebase.org; searched on 19 September 2017.

HANYUDA T., WAKANA I., ARAI S., MIYAJI K., WATANO Y. \& UEDA K., 2002 — Phylogenetic relationships within Cladophorales (Ulvophyceae, Chlorophyta) inferred from 18S rRNA gene sequences, with special reference to Aegagropila linnaei. Journal of phycology 38: 564571.

HARVEY W.H., 1858 - Nereis Boreali-Americana: or, contributions to a history of the marine Algae of North America. Part III. Chlorospermeae. Smithsonian contributions to knowledge 10(2): 1-140, pls 37-50.

HAUCK F., 1884 - Die Meeresalgen Deutschlands und Österreichs. In: RABENHORST L. (ed.), Kryptogamen-Flora von Deutschland, Österreich und der Schweiz, Zweite Auflage. Vol. 2, pp. 321-512. Leipzig: Euard Kummer.

HUANG B., TENG L. \& DING L., 2016 - Morphological and molecular discrimination of green macroalgae Chaetomorpha aerea and C. linum. Acta oceanologica Sinica 35: 118-123.

JOHN D.M., LAWSON G.W. \& AMEKA G.K., 2003 — The Marine Macroalgae of the Tropical West Africa Sub-region. Beihefte zur Nova Hedwigia, Berlin, 217 p.

KÜTZING F.T., 1843 — Phycologia generalis oder Anatomie, Physiologie und Systemkunde der Tange. Mit 80 farbig gedruckten Tafeln, gezeichnet und gravirt vom Verfasser. pp. [part 1]: [i]-xxxii, [1]-142, [part 2:] 143-458, 1, err.], pls 1-80, Leipzig: F.A. Brockhaus.

KÜTZING F.T., 1845 - Phycologia germanica, d. i. Deutschlands Algen in bündigen Beschreibungen. Nebst einer Anleitung zum Untersuchen und Bestimmen dieser Gewächse für Anfänger. Nordhausen: W Köhne. pp. i-x, 1-340.

KÜTZING F.T., 1847 — Diagnosen und Bemerkungen zu neuen oder kritischen Algen. Botanische Zeitung 5: 164-167.

KÜTZING F.T., 1849 — Species algarum. Lipsiae [Leipzig]: F.A. Brockhaus. pp. [i]-vi, [1]-922.

KÜTZING F.T., 1853 - Tabulae phycologicae; oder, Abbildungen der Tange. Vol. III. Nordhausen: Gedruckt auf kosten des Verfassers (in commission bei W. Köhne), 28 p., 100 pls.

LAGERHEIM G., 1887 — Ueber die Süsswasser-Arten der Gattung Chaetomorpha Kütz. Berichte der Deutschen Botanischen Gesellschaft 5: 195-202, pl. IX.

LELIAERT F. \& BOEDEKER C., 2007 - Cladophorales. In: BRODIE J., MAGGS C.A. \& JOHN D.M. (eds.), Green Seaweeds of Britain and Ireland. Natural History Museum Publications, London, pp. 131-183.

LELIAERT F., ROUSSEAU F., DE REVIERS B. \& COPPEJANS E., 2003 - Phylogeny of the Cladophorophyceae (Chlorophyta) inferred from partial LSU rRNA gene sequences: is the recognition of a separate order Siphonocladales justified? European journal of phycology 38: 233-246.

LELIAERT F., DE CLERCK O., VERBRUGGEN H., BOEDEKER C. \& COPPEJANS E., 2007 Molecular phylogeny of the Siphonocladales (Chlorophyta: Cladophorophyceae). Molecular phylogenetics and evolution 44: 1237-1256.

LELIAERT F., RUENESS J., BOEDEKER C., MAGGS C.A., COCQUYT E., VERBRUGGEN H. \& De CLERCK O., 2009 - Systematics of the marine microfilamentous green algae Uronema curvatum and Urospora microscopica (Chlorophyta). European journal of phycology 44: 487-496.

LELIAERT F., PAYO D. A., CALUMPONG H.P. \& De ClERCK O., 2011 - Chaetomorpha philippinensis (Cladophorales, Chlorophyta), a new marine microfilamentous green alga from tropical waters. Phycologia 50: 384-391.

MARGALEF R., 1950 - Materiales para una flora de algas del NE de España. IIIb. Euchlorophyceae. Collectanea botanica (Barcelona) 2(3): 273-294.

MONTAGNE [J.F.] C., 1841 — Plantae cellulares. In: BARKER-WEBB P. \& BERTHELOT S. (eds), Histoire naturelle des Iles Canaries. Vol. 3, Paris, pp. 161-208.

MONTAGNE [J.F.] C., 1846 - Flore d'Algérie. Ordo I. Phyceae Fries. In: DURIEU DE MAISONNEUVE M.C. (eds), Exploration scientifique de l'Algérie pendant les années 1840, 1841, 1842... Sciences physiques. Botanique. Cryptogamie, Vol. 1. Paris: Imprimerie Royale, publiée par ordre du Gouvernement et avec le concours d'une Commission Académique, $197 \mathrm{p}$. 
MORO I., RASCIO N., LA ROCCA N., SCIUTO K., ALBERTANO P., BRUNO L. \& ANDREOLI C., 2010 - Polyphasic characterization of a thermo-tolerant filamentous cyanobacterium isolated from the Euganean thermal muds (Padova, Italy). European journal of phycology 45: 143-154.

MÜLLER O.F., 1778 - Flora danica. Vol. 5, fasc. 13, Havniae [Copenhagen], 8 p., pls 721-780.

MYSTIKOU A., ASENI A.O., De CLERCK O., MÜllER D.G., PETERS A.F., TSIAMIS K., FLETCHER K.I., WESTERMEIER R., BRICKLE P., van WEST P. \& KÜPPER F.C., 2016 - New records and observations of macroalgae and associated pathogens from the Falkland Islands, Patagonia and Tierra del Fuego. Botanica marina 59: 105-121.

NIZAMUDDIN M., 1991 — The green marine algae of Libya. Bern: El-Faateh University, Department of Botany, $230 \mathrm{p}$.

PIGNATTI S. \& GIACCONE G., 1967 — Flora sommersa del Golfo di Trieste. Studi sulla produttività primaria del fitobentos nel Golfo di Trieste. I. Nova thalassia 3: 1-17.

RIZZI L., PIGNATTI S. \& DE CRISTINI P., 1967a - Contribuzione alla flora algologica del litorale Garganico meridionale fra Manfredonia e Mattinata. Giornale botanico Italiano 101: 131-132.

RIZZI L., PIGNATTI S. \& FROGLIA C., 1967b - Flora delle Acque circostanti 1'Isola di Pianosa (Is. Tremiti). Giornale botanico Italiano 101: 237-239.

RIZZI LONGO L., 1972a — La flora sottomarina delle isole Tremiti. Atti del reale istituto Veneto di scienze, lettere ed arti 130: 329-376.

RIZZI LONGO L., 1972b - Campionamenti di fitobentos lungo le coste dell'Argentario. Archivio botanico e biogeografico Italiano, 48, Ser. 4, 17 (I-II):65-73.

RODRÍGUEZ y FEMENIAS J.J., 1889 - Algas de las Baleares. Anales de la sociedad Española de historia natural 18: 199-274, pls III, iV.

SCHIFFNER V., 1916 — Studien über algen des adriatischen Meeres. Helgoländer Wissenschaftliche Meeresuntersuchungen 11: 127-198.

SCHIFFNER V. \& VATOVA A., 1937 - Le alghe della Laguna di Venezia. Estratto dalla Monographia "La laguna di Venezia" Vol. III, Parte V. Tome IX. Venezia: C. Ferrari, 174 pp., Tav. XXIIILVII, Tab. I-X.

SFRISO A., 2010 - Chlorophyta multicellulari e fanerogame acquatiche - Ambienti di transizione italiani e litorali adiacenti. I quaderni di Arpa. Arpa Emilia Romagna. Bologna, 318 p.

SFRISO A. \& CURIEL D., 2007 - Check-list of seaweeds recorded in the last 20 years in Venice Lagoon, and a comparison with the previous records. Botanica marina 50: 22-58.

SFRISO A., CURIEL D. \& RISMONDO A., 2009 - The Lagoon of Venice. In: CECERE E., PETROCELLI A., IZZO G. \& A. SFRISO (eds), Flora and vegetation of the Italian transitional water systems. Lagunet, Italian network for lagoon research, CORILA, Venezia, pp. 17-80.

SILVA P.C., BASSON P.W. \& MOE R.L., 1996 - Catalogue of the benthic marine algae of the Indian Ocean. University of California Publications in Botany, California, $1259 \mathrm{p}$.

STEGENGA H. \& MOL I., 1983 - Flora van de Nederlandse zeewieren [Flora of the Dutch seaweeds]. Natuurhistorische Bibliotheek van de KNNV, 33. Koninklijke Nederlandse Natuurhistorische Vereniging (KNNV): Hoogwoud, Netherlands, 263 p.

TAMURA K., 1992 - Estimation of the number of nucleotide substitutions when there are strong transition-transversion and $\mathrm{G}+\mathrm{C}$ content biases. Molecular biology and evolution 9: 678687.

TAMURA K., PETERSON D., PETERSON N., STECHER G., NEI M. \& KUMAR S., 2011 — MEGA5 molecular evolutionary genetics analysis using maximum likelihood, evolutionary distance, and maximum parsimony methods. Molecular biology and evolution 28: 2731-2739.

THIERS B., 2017 — Index Herbariorum: a global directory of public herbaria and associated staff. New York Botanical Garden's virtual herbarium. http://sweetgum.nybg.org/ih/ (searched on 30 November 2017).

THOMPSON J.D., HIGGINS D.G. \& GIBSON T.J., 1994 - Improving the sensitivity of progressive multiple sequence alignment through sequence weighting, position-specific gap penalties and weight matrix choice. Nucleic acids research 22: 4673-4680.

VATOVA A., 1940 - Distribuzione geografica delle alghe nella Laguna veneta e fattori, che la determinano. Thalassia 4 (2): 3-37.

WEBER F. \& MOHR D.M.H., 1804 - Naturhistorische Reise durch einen Theil Schwedens. Göttingen: Bei Heinrich Dietrich. pp. [i]-xii, [13] -207 [-208], 3 pls.

ZANARDINI G., 1840 '1839' — Species algarum novae vel minus cognitae. Biblioteca italiana 5: 134-137.

ZANARDINI G., 1843 - Saggio di classificazione naturale delle Ficee del Dottore Giovanni Zanardini aggiunti nuovi studii sopra l'androsace degli antichi con tavola miniata ed enumerazione di 
tutte le specie scoperte e raccolte dall'autore in Dalmazia, Venezia [Venice]: Dallo Stabilimento tipographico enciclopedico di Girolamo Tasso pp. [1]-64, 2 folded tables, 1 col. pl.

ZANARDINI G., 1847 - Notizie intorno alle cellulari marine delle lagune e de'litorali di Venezia (I). Atti del reale istituto Veneto di scienze, lettere ed arti 6: 185-262, $1 \mathrm{pl}$.

ZANARDINI G., 1858 (1857') - Plantarum in mari Rubro hucusque collectarum enumerato (juvante A. Figari). Memoirie del reale istituto Veneto di scienze, lettere ed arti 7: 209-309, pls IIIXIV.

ZHANG X., ZHOU Y., LIU P., WANG F., LIU B., LIU X., XU Q. \& YANG H., 2014 - Temporal pattern in the bloom-forming macroalgae Chaetomorpha linum and Ulva pertusa in seagrass beds, Swan Lake lagoon, North China. Marine pollution bulletin 89: 229-238. 